\title{
Holothuria (Cystipus) casoae a new species of sea cucumber (Echinodermata: Holothuroidea) from the central-eastern Pacific Ocean
}

\author{
ALFREDO LAGUARDA-FIGUERAS and FRANCISCO A. SOLÍS-MARÍN \\ Laboratorio de Sistemática y Ecología de Equinodermos, Instituto de Ciencias del Mar y Limnología, Universidad \\ Nacional Autónoma de México, Apdo. Post. 70-305, México, D.F. 04510. E-mail: laguarda@icmyl.unam.mx
}

\begin{abstract}
SUMMARY: Holothuria (Cystipus) casoae n. sp. is described from the central-eastern Pacific, from depths between 45 and $100 \mathrm{~m}$. The main characters separating $H$. (C.) casoae from the rest of the species included in the subgenus Cystipus are the presence of a prominent fringe of 10 or more conical papillae along each side of the body and the presence of tables with a spinose rim, the pillars of the spire are short ending in a complex spiny crown with a small central circular opening. This new species is distinctive in the genus Holothuria, subgenus Cystipus, but shows some similarities to $H$. (C.) cubana Ludwig, 1875, H. (C.) inhabilis Selenka, 1867 and H. (C.) pseudofossor Deichmann, 1930.
\end{abstract}

Keywords: Echinodermata, Holothuroidea, Holothuria, new species, Gulf of California, Costa Rica.

RESUMEN: Holothuria (Cystipus) CASOAE UNA NUEVA ESPECIE DE holoturia (ECHinOdermata: Holothuroidea) DEL Océano Pacífico oriental central. - Holothuria (Cystipus) casoae n. sp. se describe para el Pacífico Central Este, a profundidades de 45-100 m. Los principales caracteres que separan a $H$. (C.) casoae del resto de las especies incluidas en el subgénero Cystipus son: la presencia de un margen lateral formado por 10 o más papilas cónicas a cada lado del cuerpo, y la presencia de espículas en forma de tablas con borde espinoso, con espiras de pilares cortos, terminando en una corona compleja de pequeñas espinas y con un agujero central. Esta nueva especie pertenece al género Holothuria, subgénero Cystipus, pero muestra algunas similitudes con sus congéneres $H$. (C.) cubana Ludwig, 1875, H. (C.) inhabilis Selenka, 1867 and $H$. (C.) pseudofossor Deichmann, 1930.

Palabras clave: Echinodermata, Holothuroidea, Holothuria, nueva especie, golfo de California, Costa Rica.

\section{INTRODUCTION}

Holothuriidae comprise a large, worldwide-distributed family of aspidochirotid sea cucumbers of which several species are of high commercial value. In the past, their classification was extremely unstable. Pearson (1914) was the first who tried to arrange the mass of species under the name Holothuria Linnaeus, 1767 into manageable groups. As he was working on specimens that mainly originated from the Indian Ocean, his analysis was bound to be incomplete for the distribution of Holothuria, which is (now) known to be almost cosmopolitan (Tortonese, 1965; Rowe, 1969; Tommasi, 1969; Clark and Rowe, 1971; Maluf, 1988; Hendler et al., 1995; Massin, 1999; Samyn and Massin, 2003). Within the genus Holothuria, Pearson (1914) recognized five subgenera: Bohadschia, Actinopyga, Argiodia, Halodeima and Thymiosycia. When Panning (1929-1935) reviewed the mass of species under Holothuria he recognized Actinopyga, Bohadschia, Holothuria and Microthele as subgenera but retained the majority of the species under Holothuria sensu stricto. In 1944 Panning revised this perspective and 
elevated Actinopyga, Bohadschia and Microthele to generic rank. Deichmann (1958) later revaluated Holothuria on the basis of new east Pacific material. But Deichmann (1958) did not recognize the genus Holothuria sensu Linnaeus, 1758 thereby disregarding the official list of generic names in zoology (see Rowe, 1969).

Rowe (1969) revised the Holohturiidae and suggested that the Deichmann taxa should be regarded as subgenera rather than genera, and stated that she was the only specialist after Panning (1929-1944) who had attempted to simplify the chaotically organized mass of species into more manageable groups. Rowe (1969) also stated that Brandthothuria Deichmann, 1958 and Paramicrothele Caso, 1964 are junior synonyms of Thymiosycia Pearson, 1914; Fossothuria Deichmann, 1958 and Jaegerothuria Deichmann, 1958 are junior synonyms of Cystipus Haacke, 1880; Ludwigothuria Deichmann, 1958 is the junior synonym of Halodeima Pearson, 1914; and Microthele sensu Deichmann, 1958 has nothing to do with Microthele Brandt, 1835, hence Microthele sensu Deichmann, 1958 was replaced with a new subgenus, i.e. Platyperona Rowe, 1969. Rowe (1969) formed five new subgenera to accommodate the remaining species. Later on, two other subgenera, Stichothuria and Roweothuria were added by Cherbonnier (1980) and Thandar (1988) respectively.

Currently, the Holothuriidae contain some 175 to 180 species that are assumed valid. They are nowadays classified into five nominal genera: Actinopyga Bronn, 1860; Bohadschia Jaeger, 1833; Labidodemas Selenka, 1867; Pearsonothuria Levin, Kalinin \& Stonik, 1984 and Holothuria Linnaeus, 1767. The latter is further subdivided into 20 subgenera.

The purpose of this paper is to describe a new species of Holothuria (Cystipus) from the centraleastern Pacific coast.

\section{MATERIALS AND METHODS}

The material originates from three scientific collections: Colección Nacional de Equinodermos, Instituto de Ciencias del Mar y Limnología, Universidad Nacional Autónoma de México (ICMLUNAM), Los Angeles County Museum (LACM), and National Museum of Natural History, Smithsonian Institution (USNM).

Ossicles were extracted from pieces of skin (4 $\mathrm{mm}$ square) from the mid-dorsal and mid-ventral body wall, tube feet, papillae and tentacles. The skin was dissolved in fresh household bleach in centrifuge tubes. After centrifugation at $2750 \mathrm{rpm}$ for 10 minutes, bleach was pipetted off and the ossicles were flooded and centrifuged three times with ethyl alcohol. After drying, suitable ossicles were criticalpoint dried, mounted on a cylindrical double coated conductive carbon tape stub, sputter coated with gold, and photographed using a Leica Stereoscan 440 LaB6 scanning electron microscope (SEM).

\section{SYSTEMATICS}

Order AsPIDOCHIROTIDA Grube, 1840

Family HoLOTHURIIDAE Ludwig, 1894

Genus Holothuria Linnaeus, 1767

Subgenus Cystipus Haacke, 1880

Diagnosis (after Rowe, 1969: 155). Tentacles 20; pedicels more or less confined to the ventral ambulacral areas, papillae small and scattered dorsally, a lateral flange of papillae sometimes evident, anal papillae and "collar" of papillae around the base of the tentacles not apparent; body wall not very thick, usually about 2 (1-8) $\mathrm{mm}$, often gritty to the touch; body rather vermiform or dorsoventrally flattened; size small to moderate, up to $200 \mathrm{~mm}$ long; calcareous ring fairly stout with radial plates as long as the interradial plates; ossicles consisting of tables with usually knobbed disc and low spire bearing many short spines, which are sometimes so numerous and closely crowded that they may almost obscure the disc or become connected to the knobs on the margin of the disc forming a fenestrated sphere, buttons usually simple with large regularly or irregularly arranged knobs and generally 3-4 pairs, but up to 7 pairs, of relatively small holes which may become obscured somewhat by the immensity of the knobs, buttons rarely modified into fenestrated ellipsoids.

Type species. Cystipus pleuripus Haacke, 1880, by monotypy; as a synonym of Stichopus rigidus Selenka, 1867 (according to Deichmann, 1958).

\section{Holothuria (Cystipus) casoae n. sp.}

(Figs. 1-3)

Material examined: Holotype and 4 paratypes deposited at UNAMICML. Holotype UNAM-ICML 5.150.0, total length $185 \mathrm{~mm}$ (measured along the outside of curved body), 1 September, 1960, 


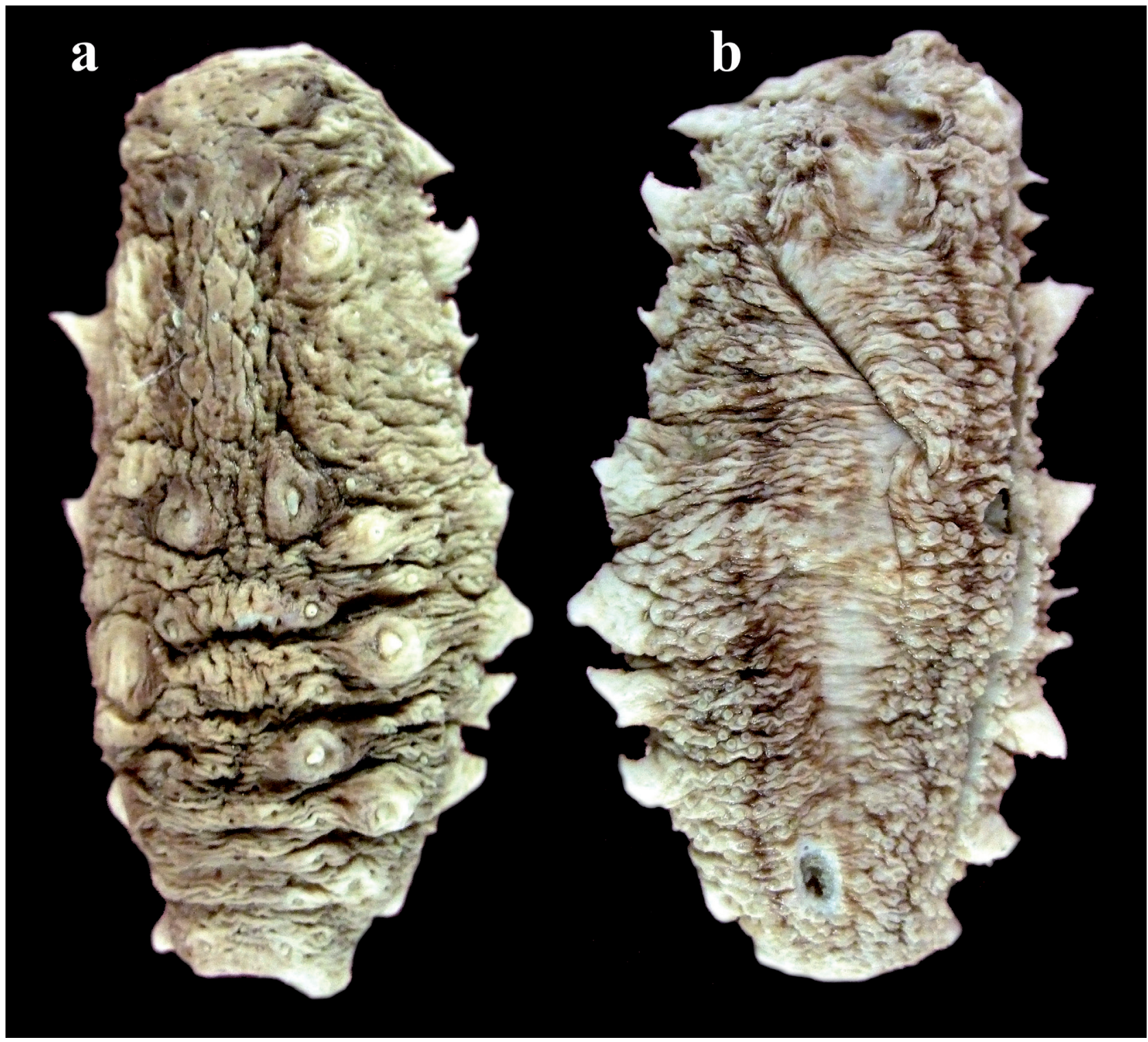

FIG. 1. - Holothuria (Cystipus) casoae n. sp. Holotype, UNAM-ICML 5.150.0. a, dorsal view; b, ventral view. Total length $=185 \mathrm{~mm}$.

Isla Montserrat, Gulf of California, Southern California $\left(25^{\circ} 43^{\prime} \mathrm{N}\right.$, $\left.111^{\circ} 03^{\prime} \mathrm{W}\right), 72 \mathrm{~m}$ depth, collected by Antonio García Cubas, shrimp trawl. Paratype UNAM-ICML 5.150.1, total length $185 \mathrm{~mm}$, same data as holotype. Paratype, UNAM-ICML 5.150.2, Total length 55 mm, B/O "El Puma", Cortés II, St. 21, 13 March, 1985, Cabo San Miguel, Gulf of California, Southern California, $\left(28^{\circ} 07.617^{\prime} \mathrm{N}\right.$, $\left.112^{\circ} 42.683^{\prime} \mathrm{W}\right), 95 \mathrm{~m}$ depth, collected by Juan Torres and Michel Hendrickx, shrimp trawl, on fine sand. Paratype, UNAM-ICML 5.150 .3 , total length $38 \mathrm{~mm}, \mathrm{~B} / \mathrm{O}$ "El Puma", Crucero Cortés Sta. 55,13 May, 1982, Banco Gorda, Gulf of California, $\left(23^{\circ} 08.5^{\prime} \mathrm{N}\right.$ $\left.109^{\circ} 27.4^{\prime} \mathrm{W}\right), 88 \mathrm{~m}$ depth, collected by M. Elena Caso and Michel Hendrickx, otter trawl. UNAM-ICML 5.150.4, total length $50 \mathrm{~mm}$, 29 August, 1960, Bahía de Loreto, Gulf of California, $\left(26^{\circ} 00^{\prime} \mathrm{N}\right.$ $\left.111^{\circ} 15^{`} \mathrm{~W}\right), 45 \mathrm{~m}$ depth, collected by Antonio García Cubas, shrimp trawl.

16 Paratypes deposited at LACM: Paratype, LACM 91-143, 1 specimen, total length $89 \mathrm{~mm}$, off Bahía de Chatman, Isla del Coco,

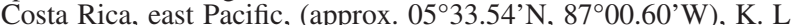
"Kaiser" (KLK 10-13II91), 10 February, 1991, 82 m. Paratypes, LACM 92-30, 6 specimens (33-100 mm total length), NW of Isla Cascara, west of Bahía Wafer, Isla del Coco, Costa Rica, east Pacific, $\left(05^{\circ} 33.15^{\prime} \mathrm{N}, 8^{\circ} 04.15^{\prime} \mathrm{W}\right), \mathrm{K}$. L. "Kaiser" (KLK 06-07IV92),
6-7 April, 1992, on sand and rubble, 95-100 m. Paratypes, 9 specimens (77-106 mm total length), Velero St. 555-36. (28 $56^{\prime} 50$ 'N, $113^{\circ} 07^{\prime} \mathrm{W}$ ), between Isla Partida and Isla Angel de la Guarda, Gulf of California, 8 March, 1936, $36 \mathrm{~m}$ ? (depth data is unreliable).

Etymology. We take great pleasure in naming this species after Dr. María Elena Caso Muñóz foremost researcher of the echinoderms of Mexico for many decades.

Description. Preserved specimens $28-85 \mathrm{~mm}$ in length. Colour in alcohol beige, trivium with two narrow light brown stripes running along the body; numerous tiny dark brown spots distributed irregularly over the dorsum. Body wall with numerous, irregular transverse wrinkles. Specimens $>90 \mathrm{~mm}$ 


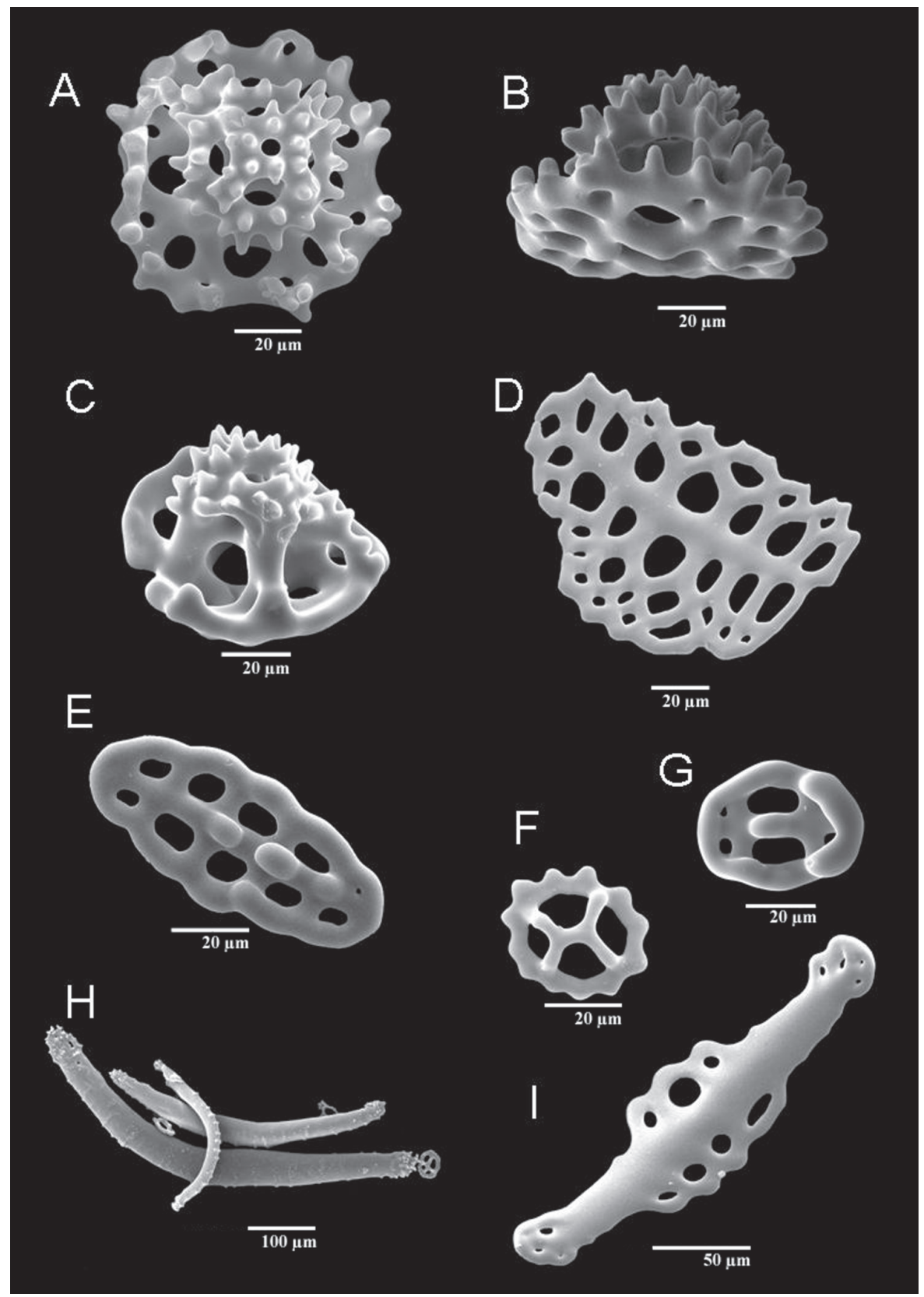

FIG. 2. - Holothuria (Cystipus) casoae n. sp. Ossicles from the holotype, UNAM-ICML 5.150.0. A, B, C, tables of the ventral body wall; D, plate from ventral tube foot; E, button of the dorsal body wall; F, rare undeveloped table from tentacle; G, small, reduced button from dorsal papillae; $\mathrm{H}$, rods from tentacles; I, rod from the ventral tube foot.

long with a prominent fringe of 10 or more conical papillae on sides. Body wall covered by scattered, short, cylindrical tube feet, distributed evenly over both the ventral and dorsal surfaces. Bivium also bears a few conical papillae of the same size as those on the lateral fringe.

Mouth ventral, surrounded by 20 white, small tentacles (holotype: 0.5 to $0.9 \mathrm{~cm}$ ). Anus terminal, with no anal papillae. Body wall up to $4 \mathrm{~mm}$ thick.

Ossicles of the ventral and dorsal body wall tables and knobbed buttons. Tables (Figs. 2A, B,
C) numerous, disc 60-90 $\mu \mathrm{m}$ across, central holes of various sizes; disc quadrangular more or less rounded with a spinose rim; pillars of spire short (0-1 cross beam) ending in a complex spiny crown with a small central circular opening. Buttons (Fig. 2E) numerous, 90-102 $\mu \mathrm{m}$ long, with 3-8 pairs of holes; rim of button knobbed. Ventral tube feet with plates, buttons, modified buttons, rods and tables. Plates (Fig. 2D) up to $100 \mu \mathrm{m}$ long, with up to five rows of holes. Rods (Fig. 2I) up to $100 \mu \mathrm{m}$ long. Tables similar in small and large specimens; disc from 

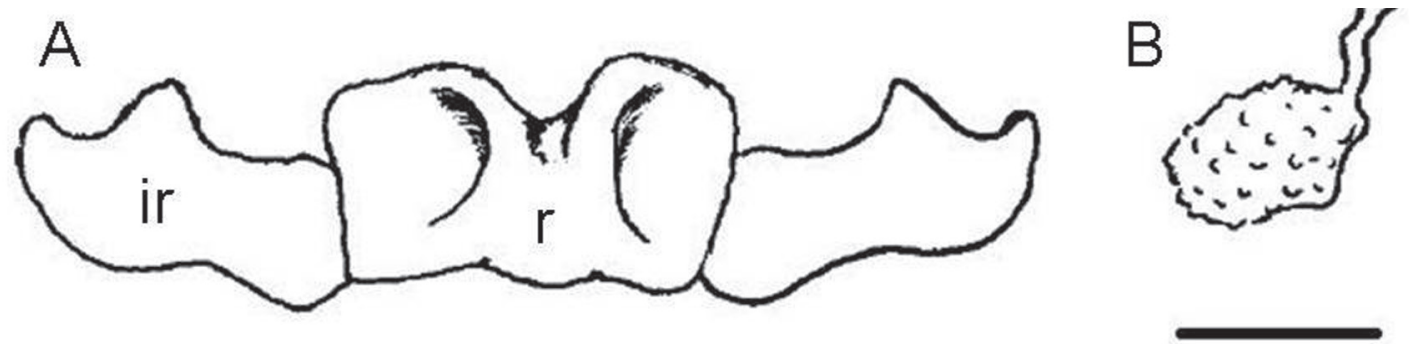

FIG. 3. - Holothuria (Cystypus) casoae n. sp. A, Calcareous ring and; B, madreporite from the holotype UNAM-ICML 5.150.0. Scale in A= $5 \mathrm{~mm}, \mathrm{~B}=1 \mathrm{~mm}$.

70 to $80 \mu \mathrm{m}$ across with a rim always more or less spinose; disc always perforated by one central hole, 8-9 medium sized holes and a variable number of smaller peripheral holes; spire variably developed, often reduced. End plate of ventral tube feet up to $700 \mu \mathrm{m}$ across. Dorsal papillae with buttons from 50-90 $\mu \mathrm{m}$ long, with 3-6 pairs of holes; tables similar to those in the body wall; small modified knobbed buttons are also present (Fig. 2G), from 46-50 $\mu \mathrm{m}$ long, with 2-3 pairs holes; more numerous in small specimens. Dorsal tube feet with tables, buttons and rods similar to those in the ventral tube feet, both in size and shape. End plate of dorsal tube feet 600-700 $\mu \mathrm{m}$ across. Tentacles with spiny to smooth rods (Fig. $2 \mathrm{H}), 270-500 \mu \mathrm{m}$ long with spiny, forked or perforated extremities; small tables under development $(\sim 38 \mu \mathrm{m}$ across) are also common (Fig. 2F).

Longitudinal muscles divided, prominent. Calcareous ring (Fig. 3A) with radial plates as wide as the length of the interradial plate. Single, well developed Polian vesicle, 1/6 of body length. Cuvierian tubules present. Stone canal very short ending in an irregular oval madreporic plate (Fig. 2B). Respiratory trees dendritic, extending forward to half the length of the body.

Distribution. Holothuria (Cystipus) casoae is known from the Gulf of California to the Isla del Coco, Costa Rica, in the central-eastern Pacific, 45100 depth, on sand and rubble sediments.

\section{DISCUSSION}

The new species clearly belongs to the subgenus Cystipus Haacke, 1880, because of the body wall which always contains tables with knobbed discs and low spires bearing many short spines, forming a variously developed crown, by the irregular buttons with 6-17 holes and the dorsal and ventral tube feet which contain similar buttons, perforated by 24 rows of holes, small plates, variously developed tables, and perforated rods.

Eleven species should now be recognized as valid in the subgenus Cystipus: Holothuria $(C$. $) \mathrm{ca}$ soae n. sp., H. (C.) cubana Ludwig, 1875; H. (C.) dura Cherbonnier and Féral, 1976; H. (C.) inhabilis Selenka, 1867; H. (C.) jousseaumei Cherbonnier, 1955; H. (C.) mammosa Cherbonnier, 1988; H. (C.) occidentalis Ludwig, 1875; H. (C.) pseudofossor Deichmann, 1930; H. (C.) rigida (Selenka, 1867); $H$. (C.) sucosa Erwe, 1919 and $H$. (C.) turrisimperfecta Cherbonnier, 1964.

This new species is distinctive in the genus Holothuria, subgenus Cystipus, but shows some similarities to $H$. (C.) cubana Ludwig, $1875, H$. (C.) inhabilis Selenka, 1867 and H. (C.) pseudofossor Deichmann, 1930.

Holothuria $(C$.) casoae is very close to the Atlantic species $H$. (C.) cubana Ludwig, 1875, as evidenced by the tables, buttons and by the presence of both spiny and smooth rods in the tentacles. However, they differ in the ossicles of the body wall: strong knobbed buttons for $H$. (C.) cubana versus weak knobbed buttons for $H$. (C.) casoae. The two species also differ in terms of their geographic distribution. H. (C.) inhabilis is a shallow water Pacific species that resembles $H$. $(C$.) casoae; however, it has fenestrated ellipsoids, which $H$. (C.) casoae does not have. Both species posses a fringe of lateral papillae on each side of the body, but it is prominent in $H$. (C.) casoae and very small, and sometimes inconspicuous in $H$. (C.) inhabilis. This fringe is also present in $H$. (C.) jousseaumei (see Cherbonnier, 1955: 147).

According to Deichmann's description, H. (C.) pseudofossor has tables with a smooth or knobbed 
rim, spire low, solid, ending in numerous teeth, and "the tables seem never to develop into such complicated forms as in the case of H. cubana". H. (C.) casoae has tables that can develop into complicated forms like in $H$. (C.) cubana.

The main characters separating $H$. (C.) casoae from the rest of the species included in the subgenus Cystipus are the presence of a prominent fringe of 10 or more conical papillae along each side of the body, the presence of tables with spinose rims, and the pillars of the spire are short ending in a complex spiny crown with a small central circular opening.

\section{ACKNOWLEDGEMENTS}

Dr. Claude Massin made a critical review of the manuscript. Many thanks to Dr. David L. Pawson, Cynthia Ahearn (Smithsonian Institution) and Dr. Yves Samyn (Brussels) who provided valuable comments on an early draft of this paper. Dr. Gordon Hendler kindly loaned the LACM material. We thank Sarita Frontana Uribe for preparing Figure 1 and the ossicles for SEM. Yolanda Ornelas (Laboratorio de Microscopía Electrónica, ICML, UNAM) for her help with SEM. We are also grateful to Alicia Duran (ICML, UNAM) for her technical support.

\section{REFERENCES}

Brandt, J.F. - 1835. Prodromus descriptionis animalium ab $H$. Mertensio in orbis terrarum circumnavigatione observatorum. Petropoli, 5(I): 1-75.

Bronn, H.G. - 1860. Die klassen und ordnungen der strahlenthiere (Actinozoa). Klassen und Ordnungen des Thier-reiches. Leipzig, (I) 2: 1-434.

Caso, M.E. -1964. Contribución al conocimiento de los holoturoideos de México. Descripción de un nuevo Subgénero del Género Microthele y una nueva especie Microthele (Paramicrothele) zihuatanensis. An. Inst. Biol., Univ. Nal. Autón. Méx., 35(1-2): 105-114.

Cherbonnier, G. - 1955. V. Les Holothuries de la Mer Rouge. Résultats Scientifiques des campagnes de la "Calypso". I. Campagne en Mer Rouge (1951-1952). Ann. Inst. Oceanogr., Paris., 30: $10-183$.

Cherbonnier, G. - 1964. Holothuries récoltées par A. Crosnier dans le Golfe de Guinée. Bull. Mus. Nat. Hist. Nat., $2^{a}$ Sér., 36(5): 647-676.

Cherbonnier, G. - 1980. Holothuries de Nouvelle-Calédonie. Bull. Mus. Nat. Hist. Nat., 4e Sér., Sec. A., 2(3): 615-667.

Cherbonnier, G. -1988. Echinodermes: Holothurides. Faune de Madagascar, 70, Editions de l'ORSTOM, París, France.

Cherbonnier, G. and J.P. Féral. - 1976. Echinodermes: Holothuries. Résultats des Campagnes Musorstom. I-Philippines (18-28 Mars 1976). Mus. Nat. Hist. Nat., 1: 357-412.
Clark, A.M. and F.W.E. Rowe. - 1971. Monograph of shallow-water Indo-West Pacific Echinoderms. London: Trust. Brit. Mus. (Nat. Hist.). London.

Deichmann, E. - 1930. The holothurians of the western part of the Atlantic Ocean. Bull. Mus. Comp. Zool., 71(3): 41-226.

Deichmann, E. - 1958. The Holothuroidea collected by the Velero III and IV during the years 1932 to 1954. Part. II Aspidochirota. Allan Hancock Pac. Exped., 11(2): 253-348.

Erwe, W. - 1919. Holothurien aus dem Rotten Meer. Mitt. Zool. Mus., 9, 2 (art. 3): 179-188.

Grube, A.E. - 1840. Actinien, Echinodermen und Würmer des Adriatischen- und Mittelmeers. J.H.B. On, Königoberg.

Haacke, W. - 1880. Holothurien. In: K. Möbius, Beiträge zur Meeresfauna der Insel Mauritius und der Seychellen. Berlin.

Hendler, G., Miller, J.E., Pawson, D.L. and P.M. Kier. - 1995. Sea Stars, sea urchins and Allies: Echinoderms of Florida and the Caribbean. Smith. Inst. Press.

Jaeger, G.F. - 1833. De Holothuriis. Turici: 1-40.

Levin, V.S., V.I. Kalinin and V.A. Stonik. - 1984. Chemical characters and taxonomic revision of holothurian Bohadschia graeffei (Semper) with reference to the erection of a new genus. Biol. Morya, 3: 33-38.

Linnaeus, C. - 1758. Systema Naturae. Ed. 10. Vol. 1: 1-824.

Linnaeus, C. - 1767. Systema Naturae. Ed. 12. Vol. 1: 1327-1336.

Ludwig, H.L. - 1875. Beiträge zur Kenntniss der Holothurien. Arb. Zool. Inst. Würzb., 2: 77-120, pls. 6-7.

Ludwig, H.L. - 1894. Reports on an exploration off the west Coast of Mexico, Central and South America, and off Galapagos Islands, in charge of Alexander Agassiz. by the U.S. Fish Commision Steamer "Albatross" during 1891: The Holothurioidea. Mem. Mus. Comp. Zool. Harv. Coll., 17(3): 1-183.

Maluf, L.Y. - 1988. Composition and Distribution of the Central Eastern Pacific Echinoderms. Nat. Hist. Mus. Los Angeles County. Tech. Rep., (2): 1-242.

Massin, C. - 1999. Reef-dwelling Holothuroidea (Echinodermata) of the Spermonde Archipielago (South-West Sulawesi, Indonesia). Zool. Verh. Nat. Naturh. Mus., 329: 1-144.

Panning, A. - 1929. Die gattung Holothuria. (1. Teil). Mitt. Zool. Staat. Zoolog. Mus. Hamb., 44: 91-138.

Panning, A. - 1934. Die gattung Holothuria. (2. Teil). Mitt. Zool. Staat. Zoolog. Mus. Hamb., 45: 24-50.

Panning, A. - 1934. Die gattung Holothuria. (3. Teil). Mitt. Zool. Staat. Zoolog. Mus. Hamb., 45: 65-84.

Panning, A. - 1935a. Die gattung Holothuria. (4. Teil). Mitt. Zool. Staat. Zoolog. Mus. Hamb., 45: 85-107.

Panning, A. - 1935b. Die gattung Holothuria. (5. Teil). Mitt. Zool. Staat. Zoolog. Mus. Hamb., 46:1-18.

Panning, A. - 1944. Die Trepangfischerei. Mitt. Hamburg. Zoolog. Mus. Inst., 49: 1-76.

Pearson, J. - 1914. Proposed reclasification of the genera Muelleria and Holothuria. Spo. Zyel., 9: 163-172.

Rowe, F.W.E. - 1969. A review of the family Holothuriidae (Holothuroidea: Aspidochirotida). Bull. Brit. Mus. (Nat. Hist.) Zool., 18(4): 119-170.

Samyn, Y. and C. Massin. - 2003. The holothurian subgenus Mertensiothuria (Aspidochirotida: Holothuriidae) revisited. J. Nat. Hist., 37(20): 2487-2519.

Selenka, E. -1867. Beiträge zur Anatomie und Systematik der Holothurien. Zeits. Wis. Zool., 17: 291-374.

Thandar, A.S. - 1988. A new subgenus of Holothuria with a description of a new species from the south-east Atlantic Ocean. J. Zool. Lond., 215: 47-54.

Tommasi, L.R. - 1969. Lista dos Holothurioidea recentes do Brasil. Cont. Inst. Oceanog., Univ. Sao Paulo. Sér. Ocean. Biol., (15): 1-29.

Tortonese, E. - 1965. Fauna d'Italia. VI. Echinodermata. Calderini, Bologna.

Scient. ed.: P. Abelló.

Received January 9, 2008. Accepted January 9, 2009.

Published online May 4, 2009. 